\title{
Cidade e Religião: a territorialidade católica da Missa da Misericórdia em Teresina-
}

\section{PI}

\author{
City and Religion: the catholic territoriality in Cult of Mercy at Teresina-PI \\ Ciudad y Religión: la territorialidad católica de la Misa de la Misericordia en Teresina-PI
}

Recebido: 16/08/2021 | Revisado: 21/08/2021 | Aceito: 24/08/2021 | Publicado: 26/08/2021

Felipe Ibiapina

ORCID: https://orcid.org/0000-0003-3087-6428

Universidade Federal de Pernambuco, Brasil E-mail: ibiapinafelipe@gmail.com

Elaine Ferreira do Nascimento ORCID: https://orcid.org/0000-0002-1632-9148 Fundação Oswaldo Cruz, Brasil E-mail:negraelaine@gmail.com

Liana Maria Ibiapina do Monte ORCID: https://orcid.org/0000-0002-8339-8477 Fundação Oswaldo Cruz, Brasil E-mail: lianaibiapina@yahoo.com.br

\begin{abstract}
Resumo
As religiões assumem papel de destaque frente à formação cultural da sociedade, influenciando na forma do humano se relacionar com o espaço. Desse modo, estudar o espaço urbano considerando a perspectiva do Sagrado possibilita um entendimento particularizado da cidade. O presente trabalho constitui um recorte da dissertação do autor, desenvolvida junto ao Programa de Pós-Graduação em Geografia da Universidade Federal do Piauí em 2018, cujo escopo investigativo recaiu sobre a análise das formas de territorialização da religião na cidade de Teresina-PI. Para o artigo, adotou-se como recorte a Missa da Misericórdia, evento católico semanal de forte apelo popular. Destaca-se que, apesar desta celebração ocorrer na circunscrição da Igreja católica, sua territorialidade e seu ethos assumem peculiaridades com relação ao território regular da paróquia. Nesse sentido, objetiva-se compreender a territorialidade sagrada erigida em torno da Missa da Misericórdia. Ancorada epistemologicamente na seara da Geografia da Religião, a pesquisa, de caráter qualitativo, adotou a etnografia como método, a partir do modelo de Geertz (2015) voltado para a descrição densa do fenômeno. Para a interpretação dos dados, buscou-se ancoragem na análise de conteúdo (Bardin, 1977).
\end{abstract}

Palavras-chave: Territorialidade; Catolicismo; Geografia da religião; Missa da Misericórdia; Teresina-PI.

\begin{abstract}
Religions play a prominent role in the cultural formation of society, influencing the way of human relating to space. Thus, studying the urban space considering the perspective of the Sacred enables a particular understanding of the city. The present work is an excerpt from the author's dissertation, developed at the Master in Geography at the Federal University of Piauí in 2018, whose investigative scope fell on the analysis of forms of territorialization of religion in the city of Teresina-PI. For the article, the Cult of Mercy was adopted as a cutout, a weekly Catholic event with strong popular appeal. It is noteworthy that, despite this celebration taking place in the circumscription of the Catholic Church, its territoriality and its ethos assume peculiarities in relation to the regular territory of the parish. In this sense, the objective is to understand the sacred territoriality built around the Cult of Mercy. Epistemologically anchored in the field of Geography of Religion, the research, of a qualitative nature, adopted ethnography as a method, based on the Geertz (2015) model aimed at the dense description of the phenomenon. To interpret the data, we sought to be anchored in content analysis (Bardin, 1977).
\end{abstract}

Keywords: Territoriality; Catholicism; Geography of religion; Cult of Mercy; Teresina-PI.

\section{Resumen}

Las religiones juegan un papel destacado en la formación cultural de la sociedad, influyendo en la forma en que los hombres se relacionan con el espacio. Así, estudiar el espacio urbano desde la perspectiva de lo Sagrado permite una comprensión particular de la ciudad. Este trabajo es un extracto de la disertación del autor, desarrollada en el Programa de Posgrado en Geografía de la Universidad Federal de Piauí en 2018, cuyo alcance investigativo recayó en el análisis de las formas de territorialización de la religión en la ciudad de Teresina-PI. Para el artículo, se adoptó como recorte la Misa de la Misericórdia, un evento católico semanal con un fuerte atractivo popular. Es de destacar que, a pesar de que esta celebración se desarrolla en la circunscripción de la Iglesia Católica, su territorialidad y su ethos asumen peculiaridades en relación al territorio regular de la parroquia. En este sentido, el objetivo es 
comprender la territorialidad sagrada construida alrededor de la Misa de la Misericórdia. Anclada epistemológicamente en el campo de la Geografía de la Religión, la investigación, de carácter cualitativo, adoptó la etnografía como método, con base en el modelo de Geertz (2015) orientado a la descripción densa del fenómeno. Para interpretar los datos, buscamos estar anclados en el análisis de contenido (Bardin, 1977).

Palabras clave: Territorialidad; Catolicismo; Geografía de la religión; Misa de Misericordia; Teresina-PI.

\section{Introdução}

É fato que as práticas religiosas que compunham os costumes dos primeiros habitantes da cidade de Teresina-PI se mantiveram no decurso do tempo, acompanhando a evolução da sociedade, assumindo, na contemporaneidade, um arranjo socioespacial diverso do que se podia observar no século XIX - período de fundação da capital. Oliveira (2014) destaca que até meados do século XX as expansões urbanas ocorridas em Teresina foram balizadas pelas territorialidades religiosas, erigidas a partir da instituição dos geossímbolos católicos: Igrejas e Escolas Confessionais.

Aponta-se como exemplo a primeira expansão leste, que se deu em função da construção da Igreja de São Benedito. Segundo a narrativa de Matos (2011), no final do século XIX, os devotos buscaram nas margens do Poti a matéria-prima para edificar o templo católico. Muitos fizeram desse percurso uma penitência, por vezes acompanhada de procissões. Sobre o caminho trilhado - da margem ribeirinha até a recém construída Igreja, construiu-se a Avenida Frei Serafim, principal via da cidade, que atua como marco delineador do zoneamento urbano.

Teresina aparece, segundo dados do último censo realizado pelo Instituto Brasileiro de Geografia e Estatística (IBGE) a contemplar filiação religiosa, em 2010, como a capital mais católica do Brasil (NERI, 2011), sendo este o país com maior número de católicos. Considerando a conjunção histórica levantada que sobreleva o peso da religiosidade na formação da cidade, materializada no espaço urbano através dos geossímbolos e, sobretudo, vivenciada na prática pelos indivíduos e grupos comunitários, busca-se investigar as territorialidades religiosas que irrompem, contemporaneamente, na cidade à luz da Geografia da Religião.

Como recorte, o presente artigo se concentra na análise da territorialidade fundada pela Missa da Misericórdia, celebração que acontece semanalmente na Igreja da Santíssima Trindade, no bairro Primavera, Zona Norte da cidade. A escolha deste objeto empírico decorre da representatividade do evento para a cena cultural e religiosa da cidade, uma vez que reúne milhares de fiéis, sendo a maior celebração da cidade. Ademais, justifica-se o intento investigativo pela singularidade desta missa, cuja organização territorial e ethos se diferenciam do modelo oficial da Igreja Católica.

\section{Metodologia}

A pesquisa de caráter qualitativo, tem como base metodológica a etnografia, adotando como referencial a descrição densa de Geertz (2015). Fez-se uso de dados textuais, partindo de fontes preexistentes - materiais monográficos, sites institucionais -; fontes produzidas pelo autor, em campo - croquis, anotações em diário de campo e entrevistas gravadas -; e dados tratados pelo autor - transcrição das entrevistas e textos analíticos.

A coleta de dados empíricos assumiu como estratégia a observação participante ancorada em entrevistas individuais semiestruturadas. Para a interpretação dos dados, toma-se como base de referência a análise de conteúdo de Bardin (1977), aderindo como técnica fundamental a análise categorial que, nas palavras de Bardin (1977, p.153), "funciona por operações de desmembramento do texto em unidades, utilizando categorias segundo reagrupamentos analíticos". São categorias de análise limites espaciais; poder; geossímbolos; arquitetura; ethos; profano.

\section{Território (Sagrado) à Luz da Geografia da Religião}

A relação existente entre Geografia e Religião preexiste à moderna categorização das ciências, uma vez que o homem, 
desde a era primitiva, já "praticava geografia" e se utilizava dos conhecimentos espaciais para a construção de representações religiosas e demarcação de territórios rituais. "Na base da geografia dos primitivos, há um comportamento religioso, é através desse valor sagrado que se manifestam os 'fatos' geográficos” (Dardel, 2015, p.33).

O termo Geografia da Religião aparece pela primeira vez no final do século XVIII, relacionando-se, nesse primeiro momento, ao estudo da geografia histórica dos tempos bíblicos (Büttner, 1991 apud Rosendahl, 2008). Todavia, sua inserção como campo temático efetivo só aconteceria em meados do século XX, a partir da produção dos geógrafos: Paul Fickeler, Pierre Deffontaines, Max Sorre e David Sopher; que traçaram as discussões de base para a estruturação dessa disciplina.

A Religião, enquanto sistema de símbolos, pode ser dividida em cosmovisão (visão de mundo) - abrange o componente metafísico da crença - e ethos - componente normativo e estético -, que corresponde a sociabilidade do "devoto", ou seja, a forma como os que partilham da fé em questão são impelidos a se portarem na sociedade, em outros termos, as inclinações de ordem subjetiva que regem as atitudes dos sujeitos (Geertz, 2015).

É durante celebrações rituais que se valida a crença, onde, através dos símbolos impressos nas cerimônias, o devoto é levado a transcender para a esfera do Sagrado - condição existencial oposta ao Profano (Eliade, 1992). Geertz (2015) destaca que os rituais induzem a disposições nos indivíduos que se desenvolvem fora do espaço ritual. Nesse processo, as concepções religiosas são confirmadas, reforçando nos sujeitos a cosmovisão e o ethos relativo à religião que, de forma prática, se expressa através da sociabilidade do sujeito em suas relações comunitárias. Assim, a celebração/ritual constitui o epicentro de poder que rege o território religioso.

Por território, entende-se uma representação do espaço, fundada a partir de apropriações, concretas ou abstratas. Consiste em uma categoria geográfica que se inscreve no espaço sem, no entanto, coincidir com o mesmo. Trata-se de uma potencialidade latente que se desenvolve a partir dos atores sociais, por meio das suas relações (Raffestin, 1993).

A tessitura territorial compreende a área de atuação dos poderes que fundam o território e pode ser delineada a partir de limites lineares e zonais. Os primeiros equivalem a fronteiras mais precisas, enquanto os outros, como a conotação semântica atribui, são constituídos por zonas transicionais, agindo sobre o espaço de maneira progressiva. No caso dos territórios religiosos, por exemplo, são comuns os limites zonais, uma vez que inexiste uma soberania fixada de forma rígida, mas, difusa (Raffestin, 1993).

Outro aspecto que integra a discussão acerca das tipologias territoriais diz respeito à forma como as relações de poder se organizam no espaço. Adota-se o modelo de malha, partindo da consideração de que o território não é constituído, espacialmente, de forma homogênea. Há, no entanto, pontos que retratam os atores sociais, constituindo locais de poder e referência; e redes, de modo complementar, correspondendo às tramas de poder que se estabelecem ao conectar diferentes pontos (Raffestin, 1993).

O poder, segundo Claval (1979), decorre de duas formas elementares: o poder puro e a autoridade. No primeiro temse como pressupostos de sustentação o controle permanente, a vigilância e a repressão. Neste, a delimitação do espaço se aproxima de padrões rígidos, uma vez que a natureza da relação, que é a "dominação", exige proximidade, se desgastando a medida que os sujeitos se afastam do seu epicentro. Essa forma de poder se opõe à autoridade, cuja legitimidade passa por uma aceitação coletiva, dispensando um controle rígido.

Nessa última perspectiva, destaca-se a tradição como uma fonte de autoridade, atribuída através do costume. Este é o tipo de poder que se encontra relacionado à religião. Ele tem, como uma das principais características, a transmissão através de gerações de indivíduos por difusão direta (Claval, 1979).

No caso do Poder Pastoral, este tem por escopo dirigir os homens, orientando os devotos para o "caminho da salvação" - a vida terrena seria uma condição temporária que poderia levar, ou não, dependendo dos atos praticados, para uma plenitude no mundo espiritual, que corresponderia à vida eterna -. Nessa espécie de relação, o poder não é exercido sobre um 
território, mas, sobre uma multiplicidade de indivíduos de forma difusa (Foucault, 2015).

Foucault (2015), trazendo à tona uma perspectiva sociológica, vê o poder como uma prática social constituída historicamente, uma entidade não cognoscível em si mesma, mas através das práticas e relações (de poder) estabelecidas. Estas, por sua vez, são entendidas como algo imanente à sociabilidade, recusando a ideia de modelo - que estaria ancorado em uma pretensa Teoria Geral dos Poderes - defendendo que a investigativa dos fenômenos sociais deve estar pautada no olhar individualizado, priorizando a esfera aproximada dos micropoderes.

Os micropoderes seriam aqueles que se perfazem no nível do corpo social, apresentando tecnologia e história específicas, são independentes entre si e do poder estatal. Foucault (2015) nega que as relações de poder estejam restritas no nível do direito ou no da violência - o que muito se apregoa -, estendendo as possibilidades de sua natureza para além dos contratos e da repressão.

Não se explica inteiramente o poder quando se procura caracterizá-lo por sua função repressiva. Pois o seu objeto básico não é expulsar os homens da vida social, impedir o exercício de suas atividades, e sim gerir a vida dos homens, controlá-los em suas ações para que seja possível e viável utilizá-los ao máximo, aproveitando suas potencialidades e utilizando um sistema de aperfeiçoamento gradual e contínuo de suas capacidades (Foucault, 2015, p.20).

Tem-se, então, o controle das potencialidades humanas - discursos, gestos, atividades, comportamentos, hábitos como o intento fundamental do poder. Foucault (2015) nomeia de Poder Disciplinar a espécie de poder cuja técnica, atuante na subjetividade da interioridade humana, encontra-se voltada para fabricação de um indivíduo tipificado. Transforma o indivíduo pelo controle do tempo, do espaço, da atividade e pela utilização de instrumentos como a vigilância e o exame.

Encontra-se, nas relações que compõem as territorialidades sagradas, uma espécie de poder disciplinar. Tomando em perspectiva a ação dos símbolos religiosos sobre os sujeitos, recordando o ethos, pode-se colocar as disposições e motivações como parte desse poder instituído pela disciplina, que molda determinada comunidade.

Outra categoria de relação de poder que envolve a dimensão religiosa é o Poder Pastoral, que Foucault (2015) aponta como introduzido em Roma pelo Cristianismo primitivo. Até meados do século XVIII, o Poder Pastoral podia ser observado em associação com o macropoder estatal, quando as esferas políticas da Igreja e do Estado ainda se encontravam imbricadas. Hodiernamente, apesar das mudanças conjunturais, essa forma de poder ainda poder ser identificada em torno das comunidades cristãs.

O Poder Pastoral tem por escopo dirigir os homens, orientando os devotos para o "caminho da salvação" - a vida terrena seria uma condição temporária que poderia levar, ou não, dependendo dos atos praticados, para uma plenitude no mundo espiritual, que corresponderia à vida eterna -. Nessa espécie de relação, o poder não é exercido sobre um território, mas, sobre uma multiplicidade de indivíduos de forma difusa (Foucault, 2015).

As interações entre Poder e Território se manifestam, também, na epistemologia. Assim como o Poder assume lugar de destaque no campo da sociologia e filosofia política, decorre que o Território, enquanto categoria geográfica, tem seu foco na Geografia Política e, em menor escala, integra as discussões de outros campos do conhecimento geográfico.

No escopo da Geografia Cultural - subárea associada à Geografia da Religião -, o território é entendido como um constructo que envolve o espaço-social e espaço-cultural. Bonnemaison (2002) define o espaço-social como espaço produzido, concebido em termos de organização, enquanto o cultural é vivenciado, criado em termos de significação. A cultura penetra o espaço e desenha uma semiografia formada por sistemas espaciais, o que se define por geossímbolos.

É, pois, através dos geossímbolos que os territórios culturais e, dentre estes, os religiosos, fundam sua representação no espaço, dando suporte às relações estabelecidas entre os sujeitos. Rosendahl (2005) acentua que são múltiplas as estratégias que integram território e religião, apontando como instrumental teórico, necessário à interpretação do fenômeno religioso e suas nuances, no que tange à relação homem e território, as categorias Sagrado e Profano. 
A partir das estruturas simbólicas religiosas se erige um repertório identitário, que rompe a materialidade homogênea do profano, criando na cidade disjunções, os territórios sagrados. Parte-se da concepção de que existem territórios que estão ligados a uma ou outra dimensão do cosmos e, no caso dos territórios religiosos, há um comprometimento com o sagrado, estando permeado de signos e significados.

Acerca da inserção do território como categoria geográfica apta ao estudo dos fenômenos religiosos, Raffestin (1993) tece uma crítica acerca da epistemologia da Geografia da Religião que, por muito tempo, tem buscado investigar as expressões espaciais e simbólicas do fenômeno religioso sem, no entanto, considerar as relações de poder. Pontua-se que a religião, em sua complexidade, atua como instrumento de comunicação e de comunhão, manipulada pelas organizações.

[...] a religião é marcada por relações de poder cujos trunfos são exatamente o controle da energia e da informação, sob a forma de homens, de recursos e de espaços. Sendo uma organização, toda igreja se comporta da mesma maneira que qualquer outra organização: procura se expandir, reunir, controlar e gerenciar. Procura codificar todo o seu meio. A codificação pelo sagrado é até mesmo muito eficaz, pois tende a isolar do resto os homens, os recursos e os espaços que são codificados (Raffestin, 1993, p. 127).

Fica claro compreender que as religiões tendem a fundar territórios, como algo inerente à sua própria essência organizacional. Algumas vertentes, tal como o Cristianismo e o Islamismo, em virtude do caráter expansionista que se liga à doutrina teológica, acentuam essa característica, se fazendo observar ao longo da história, os caminhos percorridos por esse Sagrado, as rotas de expansão e seus territórios. Tem-se um poder religioso que é ao mesmo tempo político, econômico e cultural.

Um aspecto de destaque referente à fundação dos territórios religiosos diz respeito à estrutura organizacional da Religião, enquanto instituição, a partir da qual a Igreja coordena o poder. Põe-se em evidência a Igreja Católica Apostólica Romana em razão do recorte de estudo. Ao que tipifica como hierocracia, Rosendahl (2013) destaca algumas esferas do território eclesiástico: A Igreja (templo); demais lugares sagrados; paróquias e dioceses. Nestas, o acesso ao território é controlado e a autoridade exercida por um profissional religioso.

Acerca dos níveis hierárquicos da administração religiosa católica tem-se uma estrutura piramidal, cujo topo é a sede no Vaticano, e o segundo e terceiro níveis são, respectivamente, a diocese e a paróquia. A diocese integra a camada mais importante do ponto de vista da regulação e religiosidade católica, uma vez que faz a aproximação entre as esferas global e regional. A paróquia, enquanto unidade da circunscrição diocesana - composta por Igreja Matriz e Comunidades adjuntas constitui a principal referência para os fiéis, a ponta do Sagrado que irrompe no espaço, onde se dá a experiência religiosa e a conexão entre essa dimensão e o Profano.

Para versar sobre a experiência religiosa, ou seja, fenômeno cultural, fundado sobre o espaço simbólico, bem como tratar do alcance das ações da Igreja na esfera comunitária, faz-se apropriado recorrer a outro conceito, que se institui a partir do Território, trata-se da Territorialidade. Raffestin (1993) a concebe como um conjunto de relações que envolvem os sujeitos, dado território e a exterioridade, consistindo na "face vivida" e "face agida" do poder.

A territorialidade consiste na dimensão vivida do fenômeno que funda o território, estabelecida, espacialmente, através da oscilação entre os pontos fixos e móveis - lugares e itinerários - compreendendo desde o território, marcado pela identidade, como também, o espaço que se abre para a liberdade, na circunscrição da exterioridade (Bonnemaison, 2002).

Raffestin (1993) reafirma que o entendimento da territorialidade requer a consideração do contexto na qual ela foi construída, os lugares em que ela se desenvolve e os ritmos por ela implicados. Existe uma parte interna, um núcleo denso, e a parte externa, que dialoga com os atores externos.

A territorialidade envolve dimensões de ordem objetiva e subjetiva do sistema territorial, priorizando, em seu escopo, o viés da experiência humana coletiva, as relações desenvolvidas entre os sujeitos que compartilham dos mesmos ideais e a 
exterioridade, suscitando a construção de valores de identidade e diferença (Silva, 2014).

Por identidade entende-se uma criação humana que surge da necessidade de autoafirmação enquanto sujeito social. A identidade nunca é descoberta, mas inventada a partir do zero, conforme assegura Bauman (2005). A existência cultural do homem implica na adesão a sistemas simbólicos que culminam em dada cosmovisão e ethos, que estão a moldar as decisões dos indivíduos, seu agir.

A aproximação do sujeito individual com os seus pares, ou seja, aqueles que compartilham de valores e ideias próximas, tende a fundar a consciência de identidade e de grupo. A Diferença, por sua vez, abrange a exterioridade, o que não está dentro do conjunto que perfaz o grupo. Se a identidade for vista como polo positivo da identificação cultural, a diferença consiste no negativo. São dois vieses indissociáveis de uma mesma concepção. O processo de identificação é antes exclusivo do que inclusivo, ou seja, parte-se da negação: o indivíduo olha o todo cósmico com estranheza e busca refugiar-se em um lugar de identidade.

Identidade e Territorialidade se interceptam e estabelecem uma relação de reciprocidade, no que tange ao processo cultural a territorialidade subsidia a construção da identidade e é, ao mesmo tempo, amalgamada por esta, uma vez que a identidade promove o sentido de unidade, fortalecendo a sociabilidade dos sujeitos que participam da articulação da territorialidade.

Para compreender o paralelo entre as categorias teóricas suscitadas utiliza-se como base a instância da comunidade entendida, nesse caso, como um agrupamento de sujeitos que compartilham um sistema simbólico, e se afinizam em termos de ideias e princípios -. Bauman (2005) aponta dois modelos de comunidade: a fechada e a aberta.

$\mathrm{Na}$ comunidade fechada o sentido de pertencimento do sujeito, tomando a acepção mais estrita da palavra, aparece mais forte, uma vez que se encontram estabelecidos elementos de coesão mais rígidos, que garantem uma condição espacial fixadora. No caso das relações de poder, as comunidades fechadas assumem a forma de territórios com fronteiras bem delimitadas.

Já nas comunidades abertas, existe uma maior fluidez: os sujeitos que formam esses agrupamentos sociais o fazem em razão da aproximação ideológica, ou seja, a identidade é o cerne dessa morfologia social. Bauman (2005) ressalta que na contemporaneidade, tempo "líquido" (fugaz), em meio a um mundo fragmentado, a identidade se apresenta frágil e provisória.

As comunidades abertas destacam-se nessa conjuntura, uma vez que facilitam a permuta dos sujeitos que coexistem em diversos grupos: comunidade religiosa, comunidade escolar, comunidade política, etc. Nos termos do poder, independente do material ideológico, as tipologias comunitárias abertas tendem a adotar formas de estruturação difusa, sendo demarcadas por fronteiras virtuais, expressa numa descontinuidade espacial - o que se enquadra como territorialidade.

Posto a associação entre as categorias sociológicas e geográficas aludidas, particulariza-se o olhar para a espécie de fenômeno investigado: a territorialidade religiosa. Esta é constituída por práticas produzidas por instituições ou grupos religiosos a fim de controlar determinado território carregado de sacralidade e, portanto, portador de uma identidade de fé. São as experiências religiosas que fortalecem e dão sentido à territorialidade (Rosendahl, 2013).

Bonnemaison (2002) assinala que a territorialidade encontra-se insuflada de componentes culturais, tomando forma através dos geossímbolos. É desse modo que certo grupo cultural, a que o autor define como etnia, imprime marcas que identificam determinado território. No contexto contemporâneo, há que se considerar a fluidez dos territórios, instituídos em uma sociedade heterogênea, composta por uma multiplicidade de grupos culturais, complexos em si mesmos, com contornos mutantes e estratificações.

Sahr (2013) reforça ainda que a Igreja Católica se apresenta para um grupo externo, acumulando capital simbólico, expresso através de geossímbolos, elementos tridimensionais - tal como a arquitetura religiosa que se integra na paisagem urbana -, as procissões e celebrações em espaço público. Outras territorialidades, como a dos terreiros de umbanda e 
candomblé, se perfazem de uma rede relacional e interiorizada, numa sociabilidade, até certo ponto, marginalizada, com práticas ocultadas nos quintais particulares, de costas para o espaço coletivo, em atitude autoprotetiva frente ao preconceito histórico.

Ademais, coaduna-se com Bauman (2005) que defende uma "crise do Sagrado na modernidade". O autor levanta alguns pontos que levam à reflexão: O que é Sagrado na contemporaneidade? Qual o seu papel diante de uma consciência moderna que não é ateia, mas separa Deus dos assuntos humanos na Terra?

Se por um lado, na modernidade líquida a ideia de eternidade não se sustenta - uma vez que a preocupação com o agora não deixa espaço para o eterno - por outro, tem-se que nessa conjuntura formada por um ambiente social fragmentado, o homem vivencia uma insegurança que pode levar à Fé, como recurso de autoafirmação (Bauman, 2005).

Assim, a discussão do Sagrado no âmbito do espaço urbano não é um tema superado, nem tampouco se restringe a uma investigação puramente histórica. Entende-se que o sistema ideológico das sociedades ocidentais tende a fomentar uma onda crescente de secularização o que não significa, necessariamente, a supressão do Sagrado, mas em uma mudança nos paradigmas que definem a tênue separação entre estas duas esferas ontológicas: Sagrado e Profano.

Estar atento à dinâmica em que se processa o fenômeno do Sagrado, sob a forma das territorialidades urbanas, é tarefa dos cientistas urbanos em suas variadas interfaces - geográfica, urbanística, sociológica, antropológica, econômica, etc. fazendo mister incluir essa discussão nos parâmetros de estudos urbanos.

\section{Igreja Católica: Estratégias de Territorialização}

Por territorialização das religiões entende-se um processo de expansão do poder institucional da Igreja - comunidade de crentes e sacerdotes envoltos à mesma fé (Durkheim, 2008) - a partir da ampliação das suas redes pela conquista de novos espaços sociais. Raffestin (1993) destaca que, nestas relações de poder, a primazia é dada ao controle de energia e informação, agindo sobre os homens, recursos e espaços.

Sendo uma organização, toda igreja se comporta da mesma maneira que qualquer outra organização: procura se expandir, reunir, controlar e gerenciar. Procura codificar todo o seu meio. A codificação pelo sagrado é até mesmo muito eficaz, pois tende a isolar do resto os homens, os recursos e os espaços que são codificados. Em certos casos, foi a codificação religiosa que precedeu à codificação do Estado e este último até mesmo dela procedeu (Raffestin, 1993, p.127).

A dinâmica de territorialização impetrada pela Igreja Católica Apostólica Romana, no Brasil, guarda peculiaridades que condizem com as condições sociais, políticas e econômicas desta terra, acompanhando as transformações estruturais ocorridas desde o Período Colonial até a contemporaneidade, num processo de adaptação à conjuntura vigente.

Durante a fase do Brasil Colônia, o papel assumido pela Igreja Católica estava além da função religiosa - enquanto sistema simbólico envolto ao Sagrado - podendo, ao contrário, inferir uma maior aproximação com o universo profano, dada suas incumbências de ordem política, voltadas para a dominação do território da Terra Brasilis.

As jurisdições eclesiástica e secular dividiam o encargo sobre a organização do território, sobretudo no que concerne aos costumes e ordenamento espacial. Marx (2003) explica que tendo a Cúria Romana conferido prerrogativas aos monarcas ibéricos, objetivando a tarefa missionária, foi instituído o padroado real que tornava o Rei chefe de Estado e da Igreja.

Rosendahl (1996) destaca que a religião católica manteve, no Período Colonial, três frentes: a Coroa portuguesa - pela ação colonizadora que carregava o catolicismo como fé oficial, levando a religião da metrópole para além-mar -; os colonos habitantes da colônia mantenedores da fé e propulsores de novos formatos do catolicismo -; e as ordens religiosas enfatizando a Companhia de Jesus como a dos grandes catequizadores e principais responsáveis pela territorialização da Igreja 
nessa fase inicial (Rosendahl, 1996).

Gerir o território religioso é prerrogativa de profissionais (sacerdotais) especializados, sendo possível apreender o modelo de organização territorial a partir do arranjo administrativo adotado pela instituição. Observa-se, no caso brasileiro, a modificação das estruturas da Igreja Católica para melhor atender as estratégias de afirmação do poder (Rosendahl, 2008).

Um marco que repercute na territorialização da Igreja Católica, é a laicização do Estado, no ano de 1890. Com a queda do regime de Padroado e a emergência de vários Estados republicanos, o modelo se ajustou e ganhou nova versão. A Igreja se aproxima das classes dominantes que controlam o Estado e organiza suas obras no seio ou a partir dos interesses das classes dominantes: assim os colégios, as universidades, os partidos cristãos etc. Evidentemente trata-se de uma visão de poder sagrado articulado com o poder civil (Boff, 1981, p.19).

A separação entre a esfera do Sagrado e a sociedade civil, por meio da laicização do Estado chega a ser questionada por alguns autores, haja vista que, apesar dos direitos fundamentais alcançados pela Carta Magna de 1988 - e dentre eles a liberdade religiosa - vê-se na contemporaneidade discussões acerca da legitimidade do ensino religioso confessional nas escolas, que persiste e leva a refletir se há, de fato, uma igualdade entre as religiões.

Fato é que a Igreja Católica não goza dos mesmos privilégios que outrora e seu poder encontra-se limitado desde o ato da República. A secularização dos espaços públicos e o crescimento de outras religiões, sobretudo as evangélicas, impele a Igreja ao desenvolvimento de novas estratégias para arrebatar fiéis, manter e ampliar seus territórios.

De acordo com Gil Filho e Gil (2001), o advento da separação dos poderes religioso e estatal, ocorrido no séc XIX, fez com que a Igreja Católica se aproximasse cada vez mais da Sé Romana, adotando uma estrutura administrativa piramidal, salvaguardada as competências de cada instância de poder.

No topo, tem-se a Santa Sé - sediada no Vaticano - seguida pelo Conselho Episcopal Latino-Americano circunscrição continental na qual o Brasil está inserido -, a Conferência Nacional dos Bispos do Brasil (CNBB), Dioceses/ Arquidioceses e, na base, a Paróquia (Gil Filho \& Gil, 2001).

A Paróquia é o segmento que guarda maior aproximação com o corpo de crentes, qualificando a mesma como o sustentáculo da territorialidade católica. Gil Filho e Gil (2001) destaca a revitalização desta instância clerical durante o século XX na busca pela institucionalização das práticas devocionais do catolicismo popular, alinhando essas manifestações religiosas aos preceitos da CNBB.

O intento de abarcar o catolicismo popular - marcadamente caracterizado pela alcunha devocional aos santos e aos títulos de Jesus e Maria, erigido num modelo de conexão direta entre o indivíduo e o Sagrado (Rosendahl, 1996) - revela uma estratégia de territorialização da Igreja, visando aumentar o número de fiéis "praticantes" subordinados ao poder institucionalizado que emana do clero regular. Concorda-se com Gil Filho e Gil (2001) ao entender que é através das ações desenvolvidas na paróquia que esses fiéis são envolvidos.

Um dos instrumentos que a Igreja Católica se vale para (re)afirmar seu poder é o sincretismo - prática bastante presente na conjuntura religiosa nacional em razão da miscigenação cultural - já apontado na outra seção e aqui discutido com base em Boff (1981). Segundo o autor, apesar do Cristianismo ser uma religião revelada, tendo recebido os elementos estruturantes da sua cosmovisão diretamente de Jesus Cristo, o próprio Deus que encarnado entre os homens foi responsável por sua fundação, a Igreja Católica é também um produto humano, afinada sempre a um contexto histórico-cultural, logo, passível de inovações.

Boff (1981) relembra que a Igreja Católica objetiva a conversão de todos os povos e, para tal, ela tem se valido do sincretismo para se aproximar de cada novo contexto que ela pretende se erigir ou fortalecer poder. Nas suas palavras, "a Igreja Universal (católica) se concretiza em Igrejas particulares que o são porque dentro dos condicionamentos culturais, linguísticos, psicológicos, classistas de uma região vivem e testemunham a mesma identidade de fé” (Boff, 1981, p.158). 
Nisso, apesar da obediência aos dogmas, à palavra, à tradição e ao Papa - representante de Deus na Terra -, cada circunscrição local guarda particularidades na sua formatação, de modo a absorver parte da cultura popular para se afinar ao contexto, atraindo fiéis. É preciso ter cuidado, acentua Boff (1981), para não incorrer em sincretismos negativos, aqueles que distorcem fundamentalmente os preceitos da fé católica. A adição de credos, prática recorrente entre os brasileiros, que frequentam cultos, missas, giras de terreiro, não é bem vista aos olhos da Igreja, uma vez que não alcança fiéis, mas, frequentadores que não estão sujeitos ao poder pastoral - referência à tipologia foucaultiana -.

A proposta de investigação que este artigo adere não se atém aos territórios católicos regidos pelo poder pastoral institucionalizado. Busca-se, no entanto, adentrar em uma perspectiva mais abrangente e complexa, concernente à celebração devocional, reunidora de milhares de fiéis. A presença de católicos compromissados com as atividades pastorais, dos católicos não-regulares que vivenciam uma religiosidade própria, e até de pessoas que partilham de outros credos, compõem uma comunidade ecumênica.

O poder que coordena essa territorialidade religiosa que surgem entorno das celebrações devocionais, emana do carisma de Jesus misericordioso e eucarístico, figura central no catolicismo mas que, nesse contexto específico, ganha independência simbólica para os que vivenciam a experiência com o Sagrado.

Marca-se, então, que ao lado das estratégias de territorialização da Igreja Católica, coexistem forças paralelas, poderes que se intenta compreender, trabalho este para a próxima seção. Um aspecto dessa religiosidade ligada às celebrações devocionais católicas é a multiplicidade simbólica, impossível de ser abarcada por completo pelo fato de que, nestes casos, a cosmovisão adotada pelos frequentadores é diversificada e se sobrepõe ao modelo institucionalizado pela Igreja regular.

\section{Diante da Cruz: Celebração a Jesus Misericordioso}

Sob a denominação de Missa da Misericórdia, há pouco menos de uma década, o Pe. Nilton Pereira, pároco da Igreja da Santíssima Trindade, no bairro Primavera, estruturou uma celebração voltada para os paroquianos, para que estes pudessem vivenciar, através do louvor e adoração ao Espírito Santo, uma intimidade com o divino. A proposta era que em meio às questões do mundo profano, como os problemas enfrentados na rotina, haveria uma pausa para estabelecer um contato maior com o Sagrado, reanimar a existência em meio ao caos enfrentado no mundo material, como se adentrando em uma espécie de rotura (Eliade, 1992).

A partir desse momento dos paroquianos, de acordo com a Sra. Marineide Soares (2007) - membro do conselho paroquial da Santíssima Trindade e porta-voz do Pe. Nilton - a Missa da Misericórdia foi tomando maiores proporções, que não teriam, à priori, sido planejadas. Ela destaca a ocasião da reforma da Igreja, quando tiveram que remover o teto e as celebrações passaram a acontecer ao ar livre. A quantidade de fiéis continuou crescente, de modo que não era mais viável que essas missas voltassem a acontecer na Igreja, mesmo após a conclusão da reforma.

Atualmente, a missa acontece defronte à igreja matriz da Santíssima Trindade - na praça que se entrepõem entre o templo e a Av. Duque de Caxias -, bem como, nas suas laterais, tendo sido construído um altar externo, à esquerda, exclusivo para realização dessas celebrações de grande público que chega a somar algo em torno de 5.000 pessoas (Figura 1). 
Figura 1: Esquema da implantação da Igreja da Santíssima Trindade. Destaca-se à esquerda da igreja o espaço onde acontece a celebração da missa da misericórdia, com um altar externo. Pontua-se em " $x$ " a locação dos telões, onde são transmitidas imagens do altar para os fiéis que estão distribuídos em torno da praça e dos espaços próximos à igreja.

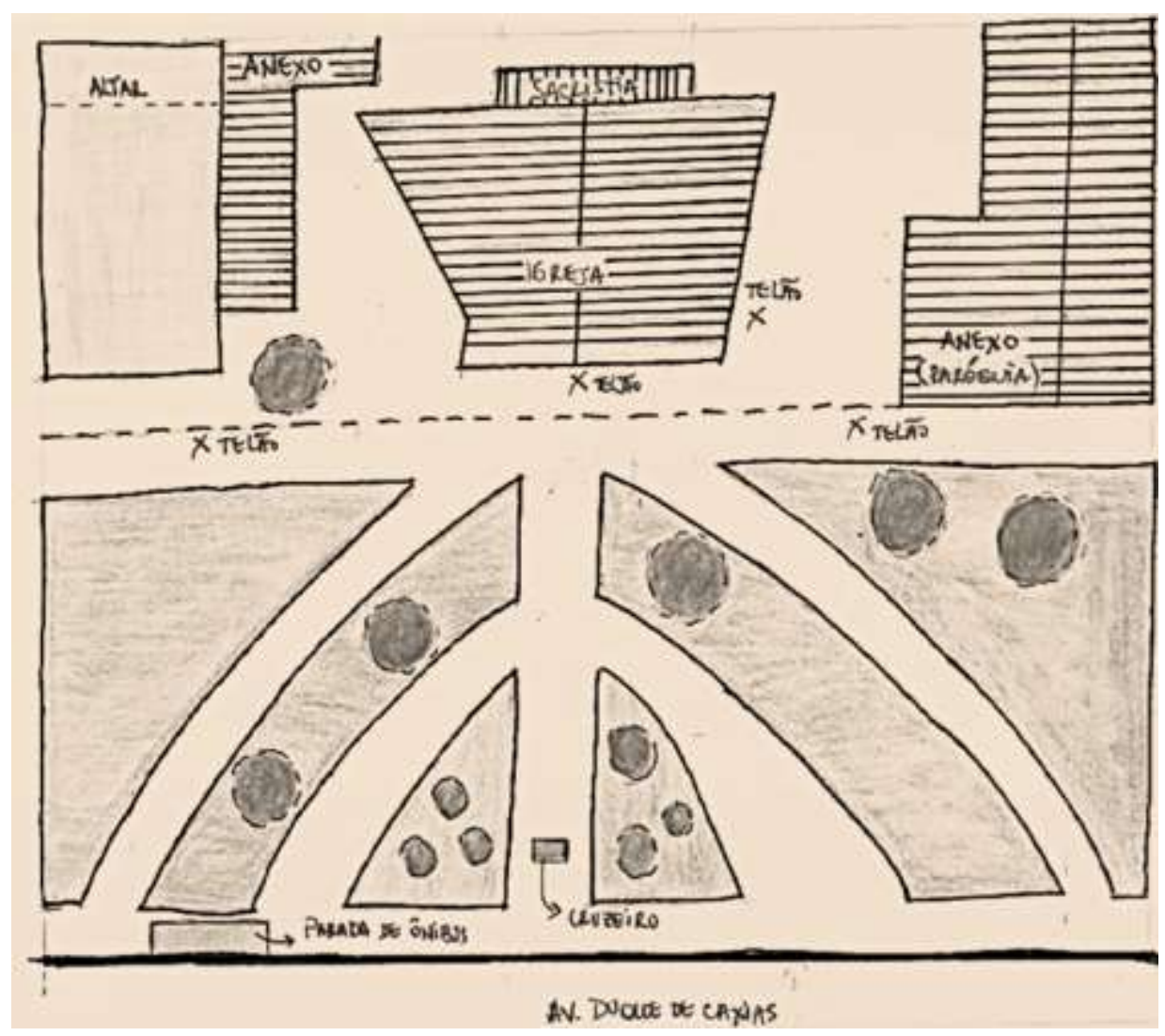

Fonte: Autores (2017).

O Sagrado sai do compartimento arquitetônico que é a igreja - templo -, e toma espaços profanos, que virtualmente assumem conotação sagrada, mais precisamente às quartas-feiras, em razão da Missa da Misericórdia e seu sistema simbólico religioso. Não há uma disfunção em levar o culto para fora do espaço sacralizado - o edifício igreja -, e realiza-lo em meio profano. Pelo contrário, na Igreja primitiva esse modelo era praticado.

Ekklesial ecclesia - raíz grega do termo Igreja - significa a reunião dos cidadãos em praça pública para discussão de questões da comunidade. Reportando para o contexto religioso, "Igreja, neste sentido primitivo, é mais acontecimento que pode ocorrer debaixo de uma mangueira, na casa de um coordenador ou mesmo dentro do edifício da Igreja [...]” (Boff, 1981, p.235).

Levar a Missa da Misericórdia à praça pública não contradiz o propósito de ser Igreja. Ademais, é pontuado que os símbolos empregados ritualmente foram mantidos, uma vez que foi construído um novo altar com todos os objetos simbólicos para instituição da liturgia eucarística, não comprometendo o cerne do sistema simbólico religioso em questão.

$\mathrm{Na}$ análise da territorialidade religiosa que se constrói a partir dessa celebração observa-se na imaterialidade dos símbolos um ponto de distinção entre a Missa Misericórdia e as missas que acontecem no templo, figurando este último como geossímbolo religioso. Ao invés de se voltar para espaços simbólicos volta-se para os momentos simbólicos, tais como: a acolhida; a liturgia da palavra; o ofertório; a comunhão; e, destacado pela Sra. Marineide como o ápice, a adoração de Jesus Eucarístico.

Ela tem aquela dinâmica: tem a acolhida que é muito festiva; depois tem o ato penitencial que é demorado, que é uns quarenta minutos, quarenta e cinco minutos, onde as pessoas são levadas a contemplar a cruz de Cristo não como 
somente olhar o sentimento, mas olhar para si próprio, refletir sua vida e se voltar para Deus pedindo a misericórdia, é o momento da misericórdia; depois tem o momento da oferta, da liturgia da palavra, onde a palavra é proclamada e o padre escolhe um evangelho para cada semana, que Deus inspira para aquele momento, onde aquele evangelho vai tocar as pessoas, aquela palavra vai entrar no coração das pessoas, então, o evangelho é, também, inspirado por Deus naquele dia; e depois o ofertório, e nesse ofertório, o padre teve uma inspiração de convidar as crianças, os bebês que estavam, muitas mães vêm com bebês, trazer as crianças para oferecer no altar, para apresentar no altar do Senhor, são crianças que se apresenta até seis meses de vida, como se fazia antigamente, Jesus foi apresentado no templo [...]; depois nós temos o momento da comunhão, de todos receberem Jesus na eucaristia; e o final da missa que é o momento ápice, que é Jesus eucarístico que passeia, que anda no meio do povo, que passa no meio do povo abençoando, que é o momento da adoração, onde nós, também, conduzimos esse momento em adoração e louvor (Soares, 2017).

Essa estrutura de base da Missa da Misericórdia não difere muito do padrão das missas ordinárias, exceto pela duração de cada ato e a condução dada pelo Padre Nilton, visto na comunidade como um sacerdote que recebeu um carisma especial do espírito santo, inspirado para formatar a celebração sob um modelo único. Como a Sra. Marineide frisa: "eu até já fui convidada pra ir em algumas missas, já fui em outras missas mas não é igual, porque cada inspiração é única. E a inspiração que Deus deu pra ele [Pe. Nilton], Deus deu pra ele” (Soares, 2017).

A inspiração recebida pelo Pe. Nilton que a Sra. Marineide faz referência é, nos termos teológicos, o carisma, uma graça que foi concedida pelo Espírito Santo e aflorou no coração se manifestando através de dons que foram postos a serviço da comunidade religiosa (Boff, 1981).

A Missa da Misericórdia representa um caminho de renovação da Igreja - renovação esta que teve início ainda no século passado - cujo intento é aproximar o corpo institucional da Igreja às comunidades leigas, e à população em geral, descentralizando o poder hierárquico - pastoral -, com vistas a um reavivamento que mantenha e/ou conquiste fiéis (Boff, 1981).

Apesar da Sra. Marineide já ter relatado que a Missa não surgiu com a intenção de tomar a proporção atual, os ingredientes, digamos, utilizados explicam o "sucesso" alcançado, reforçando que a quebra da ortodoxia e a abertura aos carismas, de fato, têm efeito na dimensão da territorialidade sagrada.

Assim como na Novena de Nossa Senhora do Perpétuo Socorro, outra celebração de destaque no cenário religioso teresinense, atribui-se que o crescimento da territorialidade em volta da Missa de Misericórdia foi estimulado pelo testemunho dos fiéis participantes do culto. As suas experiências pessoais teriam sido repassadas aos familiares e amigos, difundindo que naquela Paróquia se acharia a cura para as debilidades do corpo e da alma.

O perfil dos fiéis é heterogêneo, acumulando, também, pessoas que professam diferentes credos e que vão à Missa motivadas pelos relatos, buscando, assim, conforto espiritual através do sistema simbólico da missa, expresso por sua dinâmica diferenciada.

Foi exatamente a experiência de cada um, cada pessoa que vinha, que se deixava tocar por Deus, por Jesus, que vivia a experiência do amor de Deus, a experiência de ir até a cruz, a experiência de ter uma oração diferente, de um momento diferente na sua vida, uma experiência pessoal, interior, entende? De entrega à Deus e de uma resposta de Deus para si próprio, não apenas para problemas, mas para si próprio, essas pessoas foram contando para outros [...]. Nós acolhemos todos, quando eu acolho pessoas de outras denominações, de outras religiões, eu falo de Jesus pra eles e dessa graça, desse poder e dessa fé. Não tento mudar ninguém de religião, mas falo de Deus pra eles, do amor de Deus, acima de tudo falamos do amor de Deus (Soares, 2017).

Quanto aos deslocamentos estabelecidos, traçados a partir do local de residência das pessoas e a Zona Norte de Teresina, tem-se um raio ampliado, sendo, possivelmente, a celebração que converge devotos de lugares mais distantes. É comum a presença de caravanas de outras cidades, organizadas, especialmente, para esta celebração das quartas-feiras. Diz Soares (2017): “Então é isso que acontece, tanto que o padre recebe, ele não dá conta dos convites para levar a missa da 
misericórdia para outros lugares, para outras cidades, né? Com a mesma dinâmica, com essa dinâmica que ele, que foi inspirada por ele".

A organização espacial da celebração se desenvolve como ilustrado na Figura 01, destacando-se a praça e o anexo lateral à igreja. Iniciando pelo anexo tem-se o presbitério construído sob a forma de um palco coberto, onde o padre preside os ritos da missa. Como elementos desse espaço destaca-se, a mesa do altar, o local para os comentaristas - função geralmente ocupada pela Sra. Marineide -, e a imagem de Jesus Misericordioso estampada ao fundo - figura central da celebração - .

Defronte ao palco estão dispostas fileiras de cadeiras ao ar livre para a assembleia de fiéis, ocupando todo o recorrido do anexo, deixando apenas uma circulação central. Longe de abarcar todo o público, a grande maioria das pessoas fica na praça, onde se encontram instalados telões que transmitem a celebração.

É visível um rearranjo na paisagem do espaço público imediatamente próximo à igreja, que se inicia ao final das tardes de quarta-feira. Barracas com água, comida e outros artigos do "universo profano" são armadas no meio-fio da Avenida Duque de Caxias, para servir as pessoas - muitas vindo diretamente dos seus postos de trabalho - que chegarão para a celebração. O trânsito local é impactado pelos carros dos fiéis - estacionados nas laterais da avenida e nas ruas paralelas.

Além dos estacionamentos irregulares, que mobilizam a presença de "flanelinhas", há um estacionamento privado, ao lado da praça, que compõe os serviços indiretos oferecidos em decorrência da Missa da Misericórdia. Nesse âmbito, a Sra. Marineide destaca, também, a contratação de seguranças particulares para garantir maior segurança ao evento, pontuando, porém, que o poder público oferece um suporte, enviando viaturas policiais e guardas de trânsito.

Ainda em termos de infraestrutura pública, se destaca uma parada de ônibus que está situada na calçada da praça onde acontece a missa, facilitando o acesso daqueles que não possuem transporte particular. Seja de carro, moto, ônibus ou a pé, os fiéis encontram uma forma de comparecer, quase todos com seus banquinhos para assenta-se à praça. Por volta das 19:00 horas a celebração tem início.

Como mencionado, os atos da Missa da Misericórdia não distam muito daqueles praticados na missa regular, a não ser pelo modo como esses momentos são conduzidos, formando uma mística particularizada, que seria fruto da inspiração divina. Um exemplo é a leitura do dia que não segue o calendário da Igreja, mas é suscitada pelo Espírito Santo ao Pe. Nilton, momentos antes da celebração - daí é extraída, também, sua homilia - .

A palavra proclamada - leitura bíblica - e a reflexão proposta pelo Padre tem forte apelo de doutrinação, uma diferença da Missa da Misericórdia com relação à Novena de Nossa Senhora do Perpétuo Socorro, por exemplo. Enquanto a espiritualidade na novena é inspirada pela figura de Maria unida pelas orações em comunidade, na Missa não se pode negar a influência da pregação nesses momentos de contato com o Sagrado, sempre guiados.

Não só a oração em comunidade e o contato com Jesus Misericordioso estruturariam o ethos em torno desse sistema simbólico, mas, também, o carisma pessoal do Pe. Nilton exposto nos seus discursos, onde se percebe um chamado à conversão para a fé católica e, logo, para viver o ethos orientado pelo catecismo da Igreja.

Desse modo, pode-se desprender que a Missa da Misericórdia atua na reafirmação da fé católica e, por sua representatividade simbólica, reforça a imagem citadina de capital mais católica do Brasil. Ademais, dentre as celebrações observadas é a que exerce maior efeito no espaço público, seja pela paisagem que se forma às quartas-feiras com a multidão de fiéis na praça, como também, no impacto causado ao trânsito.

A Missa da Misericórdia, dentre outras celebrações de grande público que acontecem na cidade é que imprime, espacialmente, maior efeito visual na paisagem urbana, pela ação dos sujeitos que participam desse momento sagrado. Tem-se carros estacionados ao longo da Avenida Duque de Caxias, via de tráfego considerável, sobretudo no horário da missa, repercutindo em impacto no trânsito. Meio-fio da avenida tomado por barracas e fiéis ocupando quase todo o espaço da praça, buscando um pedaço de chão com seus "banquinhos", sinalizando que aquele espaço público, profano por essência, ganha um 
tônus sagrado. A Missa da Misericórdia adentra no imaginário coletivo e nos mapas mentais: a Igreja da Missa da Misericórdia; a avenida da Missa da Misericórdia, etc.

Quanto às relações de sociabilidade, percebeu-se nas visitas que foram realizadas à territorialidade, bem como nos relatados da entrevista, que existe um apelo maior à conversão para um sistema simbólico religioso específico, no caso, a fé católica. Apesar da aceitação de pessoas que professam outras religiões, há, durante os momentos da celebração, uma forte catequese, cujo efeito, em termos práticos, é a delineação de uma territorialidade mais fechada. De certo modo, considera-se que isso repercute na formação de sujeitos a partir de um ethos com características mais ortodoxas, que tendem a defender a primazia do catolicismo frente aos demais credos.

\section{Considerações Finais}

Para compreender o papel que as territorialidades sagradas exercem contemporaneamente na cidade de Teresina é necessário evocar um entendimento mais amplo do organismo urbano, onde coexiste uma dinâmica que comporta a paisagem natural e a construída, assim como a vivência dos usuários. Se no passado, as territorialidades religiosas chegavam a se confundir com as territorialidades civis, e sua expressão no espaço se dava, sobretudo, pelos símbolos impressos na matéria construída - como os templos e o traçado urbano -, atualmente, é através da vivência dos usuários, ou seja, das suas relações de sociabilidade que se desprende a maior influência do Sagrado.

A secularização do espaço público limitou a ação do Sagrado do ponto de vista material, porém, vê-se crescente a liberdade de ação do ethos, uma vez que se multiplicaram os meios de comunicação, possibilitando níveis de sociabilidade que não se restringe à proximidade física. A própria internet, as redes sociais, atuam como instrumento de aproximação das pessoas, de contato, potencializando as trocas de informação e transmissões.

A pesquisa pôde constatar que a territorialidade sagrada da Missa da Misericórdia é formada pelas pessoas. Estas são responsáveis por estabelecer inscrições espaciais - quando se acomodam na ocasião das celebrações - e arranjos de sociabilidade, através das relações comunitárias, suas motivações e disposições.

Conclui-se que a territorialidade da Missa da Misericórdia se constitui como um fenômeno de fluxos descontínuos, onde os limites territoriais fogem à precisão cartesiana, demonstrando que o catolicismo, através dos seus geossímbolos e das relações que se retroalimentam no seio da comunidade de fiéis, continua a impactar significativamente na construção da cidade contemporânea.

Por fim, aproveitando a discussão fomentada, chama-se atenção para a importância do diálogo integrador entre as políticas de planejamento urbano com os territórios do sagrado, defendendo a necessidade de haver uma gestão urbana responsável, atenta às dimensões sociais em suas complexidades, promovendo meios de salvaguardar a cultura do lugar através de um urbanismo voltado para as pessoas. Outrossim, propõe-se uma pesquisa continuada, a fim de inventariar, a exemplo da Missa da Misericórdia, outras territorialidades sagradas que impactam a dinâmica urbana de Teresina e seu entorno.

\section{Referências}

Bardin, L. (1977). Análise de Conteúdo. Edições 70.

Bauman, Z. (2005). Identidade: entrevista a Benedetto Vecchi. Jorge Zahar Ed.

Boff, L. (1981). Igreja, carisma e poder. (2a ed.), Vozes.

Bonnemaison, J. (2002). Viagem em torno do território. In: Corrêa, R. L. \& Rosendahl, Z. Geografia Cultural: um século. EdUERJ. 3.

Braz e Silva, A. (2012). Planejamento e fundação da primeira cidade no Brasil Imperio. In: Cadernos do PROARQ (18), 217-236.

Chaves, Pe. J. (1987). Como nasceu Teresina. (2a ed.), Fundação Cultural Monsenhor Chaves. 
Research, Society and Development, v. 10, n. 11, e159101119483, 2021

(CC BY 4.0) | ISSN 2525-3409 | DOI: http://dx.doi.org/10.33448/rsd-v10i11.19483

Claval, P. (1979). Espaço e Poder. ZAHAR.

Dardel, E. (2015). O homem e a terra: natureza da realidade geográfica. Perspectiva.

Durkheim, E. (2008). As Formas elementares de vida religiosa: o sistema totemico na Australia. Paulus.

Eliade, M. (1992). O Sagrado e o profano. Martins Fontes.

Foucault, M. (2015). Microfísica do Poder. (2a ed.), Paz e Terra.

Geertz, C. (2015). A Interpretação das culturas. LTC.

Gil Filho, S. F. \& Gil, A. H. C. (2001) Identidade religiosa e territorialidade do Sagrado: Notas para uma teoria do fato Religioso. In: Rosendahl, Z. \& Corrêa, R. L. Religião, identidade e território. EdUERJ, 39-55.

Marx, M. (2003). Nosso Chão: do sagrado ao profano. (2a ed.), Editora da Universidade de São Paulo.

Matos, M. A. de O. (2011). Avenida Frei Serafim: lembranças de um tempo que não acaba. W LAGE- Alínea Publicações Editora.

Neri, M. C. (2011). Novo mapa das religiões. FGV, CPS.

Oliveira, S. B. (2014). A geo-história de Teresina na perspectiva das ações da Igreja Católica, no âmbito da educação: 1903- 1963. Tese (doutorado)Universidade Estadual do Ceará, Fortaleza.

Raffestin, C. (1993). Por uma Geografia do Poder. Ática.

Rosendahl, Z. (1996). Espaço e Religião: uma abordagem geográfica. (2a ed.), EdUERJ.

Rosendahl, Z. (2005). Território e Territorialidade: Uma Perspectiva Geográfica para o Estudo da Religião. In: X Encontro de Geógrafos da América Latina, São Paulo.

Rosendahl, Z. (2008). Os caminhos da construção teórica: ratificando e exemplificando as relações entre espaço e religião. In: Rosendahl, Z. \& Corrêa, R. L. (orgs.). Espaço e Cultura: pluralidade temática. EdUERJ, 47-78.

Rosendahl, Z. (2013). Espaço, política e religião. In: Rosendahl, Z. \& Corrêa, R. L. (orgs.). Geografia Cultural: uma antologia. EdUERJ, 2, 147-162.

Sahr, W. D. (2013). O mundo de São Jorge e Ogum: contribuição para uma geografia da religiosidade sincrética. In: Rosendahl, Z. \& Corrêa, R. L. (orgs.). Geografia Cultural: uma antologia. EdUERJ, 2, 163- 168.

Silva, T. T. da. (2014). Identidade e diferença: a perspectiva dos estudos cultuais. (15a ed.), Vozes.

Sousa, M. (2017). Entrevista concedida ao autor. 